\title{
A Review on Medicinal Plants Against Some Human Pathogenic Bacteria (E. coli, S.dysentery, S.typhi, P.aeruginosa and S. aureus) in South East Ethiopia
}

\author{
Shiferaw Belay ${ }^{1} \quad$ Addisu Assefa $^{2} \quad$ Habtamu Tedila $^{* 3}$ \\ 1..Lecturer in Robe teachers College (Applied microbiology) \\ 2.Director of post graduate in Madda Walabu University (Associate professor in Microbiology) \\ 3.Lecturer in Department of Biology (Applied Microbiology) PO box 247, Bale Robe, Ethiopia
}

DOI: $10.7176 / \mathrm{JBAH} / 9-19-03$

Publication date:October $31^{\text {st }} 2019$

\section{INTRODUCTION}

\subsection{Historical use of medicinal plants as medicine}

In many parts of the world, medicinal plants have been used as traditional treatments for various human ailments for thousands of years. The use of plant and its products has a long history in maintaining human health that began with folk medicine and through the years has been incorporated into traditional and allopathic medicine (Gislene et al., 2000; Dubey et al., 2011). Plants have a long history of use in treatment and management of different diseases all over the world since ancient times and about $25 \%$ of current drugs are derived from plants (Wanyoike et al., 2004). In certain African countries up to $90 \%$ of the population relies exclusively on plants as sources of medicines (Hostetman et al., 2000).

Medicinal plants have been recognized as potential sources of new compounds for therapeutic use. Findings from researchers and pharmaceutical entrepreneurs have pointed out that ethno botanically derived compounds have greater activity than compounds derived from random screening and thus a greater potential for novel products developed (Njoroge and Bussmann, 2006). Natural products as pure compounds or standardized plant extracts provide an unlimited opportunities for new drug leads due to their unmatched availability of chemical diversity (Parekh and Chanda, 2007). Natural products have been used in traditional medicine all over the world for thousands of years and they predate the introduction of antibiotics and other modern drugs (Balunas and Kinghorn, 2005, Parekh and Chanda, 2007). Plants are rich in a wide variety of secondary metabolites called phytochemicals such as tannins, alkaloids, and flavonoids that have been found to have antimicrobial properties. For example, the essential oil and eugenol purified from Ocimum gratissimum has been reported to treat pneumonia, diarrhea and conjunctivitis (Nakamura et al., 1999). These evidences contribute to support and quantify the importance of screening natural products.

\subsection{Contributions of plant extract compounds in the field of medicine}

Plants are known to produce a variety of compounds to protect themselves against a variety of pathogens. It is expected that plant extracts showing target sites other than those used by antibiotics will be active against drug resistant pathogens. These types of plants that are used for treatment of different diseases are so called medicinal plants (Ahmad and Beg, 2001). Medicinal plants represent a rich source of antimicrobial agents. Plants are used medicinally in different countries and are a source of many potent and powerful drugs (Srivastava et al., 1996). A wide range of medicinal plant parts is used for extract as raw drugs and they possess varied medicinal properties. The different parts used include root, stem, flower, fruit, twigs exudates and modified plant organs.

Natural products of higher plants are the probable sources of antimicrobial agents which have added advantages of being safe and biodegradable (Adenisa et al., 2000). Natural products as pure compounds or standardized plant extracts provide an unlimited opportunities for new drug leads due to their unmatched availability of chemical diversity (Parekh and Chanda, 2007). Many plants species have been used because of their antimicrobial traits ; pharmacological properties as they are known to posses various secondary metabolites called phytochemicals like glycosides, saponins, flavonoids, steroids, tannins, alkaloids, tirpenes which is therefore, should be utilized to combat the disease causing pathogens (Lalitha et al., 2010; Hussain et al. 2011).

\subsection{Significance of extraction of medicinally valuable compounds from plants}

With the advancement in Science and Technology, remarkable progress has been made in the field of medicine with the discoveries of many natural and synthetic drugs (Preethi et al., 2010). Plants may serve as natural blue prints in the development of new drugs or as phytomedicines to be used to treat disease (Abubakar et al., 2008). Antibiotics are undeniably one of the most important therapeutic discoveries of the $20^{\text {th }}$ century that had effectiveness against serious bacterial infections. However, only one third of the infectious diseases known have been treated from these synthetic products (Sharma, 2011). 
Although hundreds of plant species have been tested for antimicrobial properties, the vast majority of have not been adequately evaluated. Consequently, in recent time researchers have paid attention to advanced phytomedicines and biologically active compounds isolated from plant species used in herbal medicines with acceptable therapeutic index for the development of novel drugs (Pavithra et al., 2010).

\subsection{The in vitro antibacterial activity assay}

Introduction and development of several new and highly specific in vitro bioassay techniques, chromatographic methods, spectroscopic techniques and other standardized pharmacological methods have made much easier to screen, isolate and identify potential drug compounds quickly and precisely from natural sources to alleviate human illnesses (Satyajit et al., 2001). Antimicrobial susceptibility tests measure the ability of an antimicrobial agent to inhibit bacterial growth in vitro. This ability may be estimated by either the dilution method or the diffusion method (WHO, 2003). In vitro antimicrobial test is preferable method to carry out experiments using the crude powder of each plant extract by plate diffusion method (Ieven et al., 1979). Plants are important source of potentially useful structures for the development of new chemothera peutic agents. The first step towards this goal is the in vitro antibacterial activity assay (Tona, 1998; Mahesh and Satish, 2008).

There are many methods to test the effectiveness of antimicrobial chemicals, including the agar well diffusion, disk diffusion and dilution assay. In disc diffusion assay, small filter disks are impregnated with the chemical to be tested, and are placed on a plate inoculated to form a bacterial lawn (even, confluent bacterial growth). The plates are incubated to allow growth of the bacteria and time for the chemicals to diffuse into the agar. As a chemical diffuses into the agar, it becomes less concentrated. If an organism is susceptible to a chemical, a clear zone of inhibition will appear around the disk where the growth has been inhibited. The size of this zone of inhibition depends on the sensitivity of the bacteria to the specific chemical and the chemical's ability to diffuse through the agar (Cain et al., 2013). Disc-diffusion susceptibility tests may give unreliable results, if the appropriate technique is not strictly followed (WHO, 2003). Similarly, in agar wel difussion method, wells will be made on Muller Hinton agar plates using a sterile cork borer of appropriate diameter after which desired amount of the antimicrobial or the extract concentration to be tested will be dispensed into each well (Shahidi Bonjar, 2004). In dilution technique the antimicrobial substance diluted from its highest concentration to the lowest concentration of chemotherapeutic agent capable of preventing growth of the test organism, which gives the Minimum Inhibitory Concentration (MIC) (Abdelraouf, 2009).

\subsection{Plant materials as treatment for gastrointestinal diseases}

Infections associated with bacterial pathogens are among some of the indications for treatment with traditional remedies that include plant products (Njoroge and Busman, 2007). Medicinal plants have been reported to cure urinary tract infections, gastrointestinal disorders, respiratory diseases and cutaneous infections. For example, the essential oil and eugenol purified from Ocimum gratissimum has been reported to treat pneumonia, diarrhea and conjunctivitis (Nakamura et al., 1999). Plants are powerful remedies in the treatment of abdominal infections especially dysentery, diarrhea and gastroenteritis (Mthabe et al., 2006; Lategan et al., 2009). Several studies have shown that diarrhea and gastroenteritis are a major cause of mortality in children under 5 years in developing countries (Ouattara et al., 2013). Many researchers in Ethiopia have identified medicianl plants as a remedey for the treatment of diarreheal diseases and gastrointestinal disorders (Table 2) (Mesfin et al., 2003; Gidey and Samuel, 2005; Ermias et al., 2008; Haile et al., 2008; Fisseha et al., 2009; Nasir et al., 2011; Rainer et al., 2011; Balcha Abera, 2014; Elizabeth et al., 2014; Gemedo et al., 2014; Getaneh et al., 2014; Meseret and Egigu, 2014; Genene and Reddy, 2015; Getnet et al., 2015). In Bale zones, several traditional medicinal plants have been also utilized to treat diarreheal disease and gastrointestinal disorders among which C. aurea, V. amygdalina, and R. nepalensis are the main and frequently usable (Tableland 2) (Ermias et al., 2008; Nasir et al., 2011; Rainer et al., 2011).

1.5.1. Calpurnia aurea

Studies have indicated that the plant Calpurnia aurea (wild), locally called Cheketa or cheekaa in Afan Oromo and Digita in Amharic language belongs to the family Fabaceae found almost in all areas of Bale zone especially in Mena Angetu forest (Ermias et al., 2008; Nasir et al., 2011). Decoction of leaf, seed and root of this plant are used as medicine in Bale zone as well as in different areas of the country to treat diarrhea, bloody diarrhea and abdominal pain (Gidey and Samuel, 2005; Ermias et al., 2008; Nasir et al., 2011; Abiyu et al., 2014; Elizabeth et al., 2014; Getaneh et al., 2014; Getnet et al., 2015). 
Table 1: Common medicinal plants of Bale zone used to treat gastrointestinal problems

\begin{tabular}{|c|c|c|c|c|c|c|}
\hline \multirow[b]{2}{*}{$\begin{array}{l}\mathrm{R} / \\
\mathrm{N}\end{array}$} & \multicolumn{2}{|l|}{ Plant's Name } & \multirow{2}{*}{$\begin{array}{r}\text { Plant } \\
\text { part } \\
\text { used }\end{array}$} & \multirow{2}{*}{$\begin{array}{l}\text { Disease } \\
\text { treated }\end{array}$} & \multirow{2}{*}{$\begin{array}{l}\text { Study } \\
\text { area in } \\
\text { Bale zone }\end{array}$} & \multirow[b]{2}{*}{ Reference } \\
\hline & Scientific name & $\begin{array}{l}\text { Local Name } \\
\text { (Afan } \\
\text { Oromo) } \\
\end{array}$ & & & & \\
\hline 1 & Hypericum revolutum & Garramba & $\mathrm{L}$ & \multirow{3}{*}{$\begin{array}{l}\text { Stomach } \\
\text { problems }\end{array}$} & \multirow{6}{*}{$\begin{array}{l}\text { Odo -Bulu } \\
\text { Demaro, } \\
\text { Bale }\end{array}$} & \multirow{6}{*}{$\begin{array}{c}\text { (Rainer et } \\
\text { al., 2011) }\end{array}$} \\
\hline 2 & Cucumis ficifolius & Han'chote & $\mathrm{R}$ & & & \\
\hline 3 & Croton macrostachyus & & $\mathrm{B}$ & & & \\
\hline 4 & Ocimum sp. & Damakase & $\mathrm{L}$ & $\begin{array}{l}\text { Intestinal } \\
\text { infections }\end{array}$ & & \\
\hline 5 & Allophylus abyssinicus & Habarra & $\mathrm{F}$ & \multirow{2}{*}{$\begin{array}{l}\text { Stomach } \\
\text { problems }\end{array}$} & & \\
\hline 6 & Phytolacca Dodecandra & Endode & $\mathrm{R}$ & & & \\
\hline 7 & Asystasia guttata & Baquli & $\mathrm{R}$ & Diarrhoea & \multirow{4}{*}{$\begin{array}{l}\text { Mana } \\
\text { Angetu }\end{array}$} & \multirow{4}{*}{\begin{tabular}{|l}
$($ Ermias \\
al., 2008)
\end{tabular}} \\
\hline 8 & Barleria argentea & Hokto & R\&L & Diarrhoea & & \\
\hline 9 & Blyttia fruticulosum & Joshani & $\mathrm{B}$ & Diarrhoea & & \\
\hline 10 & Calpurina aurea & Chekata & $\mathrm{L}$ & Diarrhoea & & \\
\hline 11 & Calpurina aurea & Chekata & $\mathrm{R} \& \mathrm{~B}$ & Dysentery & Bale zone & $\begin{array}{l}\text { (Nasir et al., } \\
2011 \text { ) }\end{array}$ \\
\hline 12 & Cissampelos pareira & Baltoke & $\mathrm{R}$ & Diarrhoea & $\begin{array}{l}\text { Mana } \\
\text { Angetu }\end{array}$ & $\begin{array}{ll} & \text { Ermias } \\
\text { al., 2008) }\end{array}$ \\
\hline 13 & Cissus populnea & Gangalto & $\mathrm{R}$ & $\begin{array}{l}\text { Vomiting, } \\
\text { Diarrhea }\end{array}$ & $\begin{array}{l}\text { Mana } \\
\text { Angetu }\end{array}$ & $\begin{array}{l}\text { (Ermias et } \\
\text { al., 2008) }\end{array}$ \\
\hline 14 & Colocassia esculenta & Gondire & $\mathrm{L}$ & \multirow{6}{*}{$\begin{array}{l}\text { Vomiting } \\
\text { and } \\
\text { Diarrhea }\end{array}$} & \multirow{6}{*}{$\begin{array}{l}\text { Mana } \\
\text { Angetu }\end{array}$} & \multirow{6}{*}{$\begin{array}{l}\text { (Ermias et } \\
\text { al., 2008) }\end{array}$} \\
\hline 15 & Convolvulus siculus & LeIbab & $\mathrm{L}$ & & & \\
\hline 16 & Dioscorea quartiniana & Gishu & $\mathrm{R}$ & & & \\
\hline 17 & Hibiscus luduwigii & Bulanbula & $\mathrm{R}$ & & & \\
\hline 18 & Kleinia abyssinica & Burka & $\mathrm{R}$ & & & \\
\hline 19 & Lippia javanica & Sukahi & $\mathrm{L}$ & & & \\
\hline 20 & Lippia adoensis & Sukahi & $\mathrm{L}$ & $\begin{array}{l}\text { Abdominal } \\
\text { Irritation }\end{array}$ & $\begin{array}{l}\text { Mana } \\
\text { Angetu }\end{array}$ & $\begin{array}{ll}\text { Ermias } & \text { et } \\
\text { al., 2008) }\end{array}$ \\
\hline 21 & Oleae Cuspidata & Ejersa & $\mathrm{L}$ & \multirow{5}{*}{$\begin{array}{l}\text { Stabing } \\
\text { Pain }\end{array}$} & \multirow{5}{*}{$\begin{array}{l}\text { Mana } \\
\text { Angetu }\end{array}$} & \multirow{5}{*}{$\begin{array}{l}(\text { Ermias et } \\
\text { al., 2008) }\end{array}$} \\
\hline 22 & Olinia rochetiana & Guna & $\mathrm{L}$ & & & \\
\hline 23 & Pentas lanceolata & Dhumuga & $\mathrm{L}$ & & & \\
\hline 24 & Pittosporum viridiflorum & Ara & $\mathrm{B}$ & & & \\
\hline 25 & Pterolobium stellatum & Kejima & $\mathrm{B}$ & & & \\
\hline 26 & Rhynchosia densiflora & & $\mathrm{R}$ & \multirow{2}{*}{$\begin{array}{l}\text { Vomit and } \\
\text { Diarrhoea }\end{array}$} & Mana & \multirow{2}{*}{$\begin{array}{ll}\text { Ermias et } \\
\text { al., 2008) }\end{array}$} \\
\hline 27 & Rumex nepalensis & Shabbe & $\mathrm{R}$ & & Angetu & \\
\hline 28 & Rumex nepalensis & Shabbe & $\mathrm{R}$ & $\begin{array}{l}\text { Stomach } \\
\text { Problem }\end{array}$ & $\begin{array}{l}\text { Odo Bulu- } \\
\text { Demaro, } \\
\text { Bale }\end{array}$ & $\begin{array}{l}\text { (Rainer et } \\
a l ., 2008)\end{array}$ \\
\hline 29 & Rumex nervosus & Umbaco & $\mathrm{L}$ & $\begin{array}{l}\text { Abdominal } \\
\text { pain }\end{array}$ & Gololcha & $\begin{array}{l}\text { (Meseret \& } \\
\text { Egigu,2014) }\end{array}$ \\
\hline 30 & Solanum giganteum & & $\mathrm{R}$ & Diarrhoea & $\begin{array}{l}\text { Mana } \\
\text { Angetu }\end{array}$ & $\begin{array}{l}\text { (Ermias et } \\
\text { al., 2008) }\end{array}$ \\
\hline 31 & Stephania abyssinica & Kalala & $\mathrm{R}$ & \multirow{3}{*}{$\begin{array}{l}\text { Stabing } \\
\text { Pain }\end{array}$} & \multirow{3}{*}{$\begin{array}{l}\text { Mana } \\
\text { Angetu }\end{array}$} & \multirow{3}{*}{$\begin{array}{l}\text { (Ermias et } \\
\text { al., 2008) }\end{array}$} \\
\hline 32 & Talinum caffrum & Burka & $\mathrm{R}$ & & & \\
\hline 33 & Thalictrum rhynchocarpum & Bala/Sirebizu & $\mathrm{R}$ & & & \\
\hline 34 & Vernonia amygdalina & & $\mathrm{L}$ & $\begin{array}{l}\text { Anti- } \\
\text { dysentery }\end{array}$ & Bale zone & $\begin{array}{l}\text { (Nasir et al., } \\
2011 \text { ) }\end{array}$ \\
\hline 35 & Zinnia peruviana & & $\mathrm{R}$ & Diarrhea & $\begin{array}{l}\text { Mana } \\
\text { Angetu }\end{array}$ & $\begin{array}{ll}\text { Ermias } & \text { et } \\
\text { al., 2008) }\end{array}$ \\
\hline 36 & Alliums sativa & Qullubi adii & $\mathrm{Bu}$ & $\begin{array}{l}\text { Stomach } \\
\text { ache }\end{array}$ & Gololcha & $\begin{array}{l}\text { (Meseret \& } \\
\text { Egigu, } \\
2014)\end{array}$ \\
\hline 37 & Rubia cordifolia & Anqis & $\mathrm{R}$ & Diarrhoea & Bale Mou. & Haile et al., \\
\hline 38 & Tagetes minuta & Hada Gola & $\mathrm{L}$ & Diarrhoea & Nati. Park & 2008) \\
\hline
\end{tabular}




\begin{tabular}{|c|c|c|c|c|c|c|}
\hline \multirow[b]{2}{*}{$\begin{array}{l}\mathrm{R} / \\
\mathrm{N}\end{array}$} & \multicolumn{2}{|l|}{ Plant's Name } & \multirow{2}{*}{$\begin{array}{r}\text { Plant } \\
\text { part } \\
\text { used }\end{array}$} & \multirow{2}{*}{$\begin{array}{l}\text { Disease } \\
\text { treated }\end{array}$} & \multirow{2}{*}{$\begin{array}{l}\text { Study } \\
\text { area in } \\
\text { Bale zone }\end{array}$} & \multirow[b]{2}{*}{ Reference } \\
\hline & Scientific name & $\begin{array}{l}\text { Local Name } \\
\text { (Afan } \\
\text { Oromo) }\end{array}$ & & & & \\
\hline 39 & Gladiolus dalenii & Kelede & $\mathrm{R}$ & $\begin{array}{l}\text { Stabbing } \\
\text { Pain }\end{array}$ & $\begin{array}{l}\text { Bale Mou. } \\
\text { Nati. Park }\end{array}$ & $\begin{array}{l}\text { Haile et al., } \\
\text { 2008) }\end{array}$ \\
\hline 40 & Dovyalis abyssinica & Koshimo & W & Diarrhea & $\begin{array}{l}\text { Bale Mou. } \\
\text { Nati. Park }\end{array}$ & $\begin{array}{l}\text { (Haile et al., } \\
\text { 2008) }\end{array}$ \\
\hline 41 & Lippia adoensis & Sukayee & $\mathrm{L}$ & Diarrhea & & \\
\hline 42 & Solanum incanum & Hiddi & $\mathrm{R}$ & Stomach & Gololcha & $\begin{array}{l}\text { (Meseret \& } \\
\text { Egigu,2014) }\end{array}$ \\
\hline 43 & Solanum macracanthum & Hiddi & $\mathrm{R}$ & $\begin{array}{l}\text { health and } \\
\text { sudden } \\
\text { pain }\end{array}$ & $\begin{array}{l}\text { Odo Bulu } \\
\text { and } \\
\text { Demaro }\end{array}$ & $\begin{array}{l}\text { (Rainer et } \\
\text { al., 2011) }\end{array}$ \\
\hline 44 & Solanum adoens & Hiddi & $\mathrm{L}$ & $\begin{array}{l}\text { Abdominal } \\
\text { irritation }\end{array}$ & $\begin{array}{l}\text { Bale Mou. } \\
\text { Nati. Park }\end{array}$ & $\begin{array}{l}\text { (Haile et al., } \\
\text { 2008) }\end{array}$ \\
\hline
\end{tabular}

Key: Plant parts: Bark (B), Bulb (Bu), Flower (F), Leaf (L), Root (R), Seed (S) and Whole: plant part (W)

\subsubsection{Vernonia amygdalina}

Vernonia amygdalina commonly called bitter leaf is a homely plant that grows almost everywhere especially in the tropical areas of Africa which belongs to the family Astaraceae. It is regarded as a wonderful gift from God to mankind because of its numerous medicinal values including cure for stomach ache, skin infections, diabetes, insomnia, tooth ache, acne, pneumonia, stoke, arthritis, fatigue, cough and bleeding (Agbogidi and Akpomorine, 2013). The plant locally named Girawa or Ebicha (Amharic and Afan Oromo language respectively) has a remarkable role as anti dysentery in Ethiopia particularly in Bale's society (see table 2) (Fisseha et al., 2009; Nasir et al., 2011; Abiyu et al., 2014; Gemedo et al., 2014; Genene and Reddy, 2015).

\subsubsection{Rumex nepalensis}

The genus Rumex comprises of about 200 species of herbs. R. nepalensis belongs to the family Polygonaceae is locally known as "Tult and Shabbe", Amharic and Oromic, respectively. It grows abundantly in many parts of the country. The use of $R$. nepalensis for various therapeutic purposes is well known in Ethiopian traditional medicine, especially in Bale zone. The pounded root is given to humans in case of diarrhea, stabbing pain, abdominal colic and stomach problems (Table 2) (Mesfin et al., 2003; Ermias et al., 2008; Rainer et al., 2011; Abiyu et al., 2014; Balcha Abera, 2014; Elizabeth et al., 2014; Getnet et al., 2015). 
Table 2: Ethno-medicinal use of the three selected medicinal plants in different areas of the country

\begin{tabular}{|c|c|c|c|c|c|c|}
\hline \multicolumn{3}{|c|}{ Plant's Name } & \multirow{2}{*}{$\begin{array}{l}\text { Plant } \\
\text { part } \\
\text { used }\end{array}$} & \multirow[b]{2}{*}{ Disease treated } & \multirow[b]{2}{*}{ Study area } & \multirow[b]{2}{*}{ Reference } \\
\hline Family & $\begin{array}{l}\text { Scientific } \\
\text { name }\end{array}$ & Local Name & & & & \\
\hline \multirow{8}{*}{ 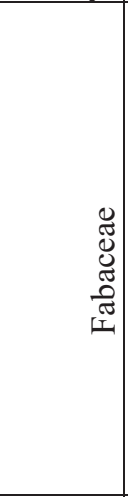 } & \multirow{8}{*}{ : } & Chekata (Oro.) & $\mathrm{L}$ & Diarrhoea/ Bassa & Mana Angetu & (Ermias et al., 2008) \\
\hline & & Chekata (Oro.) & $\mathrm{R} \& \mathrm{~B}$ & $\begin{array}{l}\text { Stomachache and } \\
\text { dysentery }\end{array}$ & Bale zone & (Nasir et al., 2011) \\
\hline & & Digita (Amh.) & $\mathrm{F}$ & Abdominal pain & Fiche & (Abiyu et al., 2014) \\
\hline & & Digita (Amh.) & $\mathrm{L}$ & $\begin{array}{l}\text { Child with } \\
\text { diarrhoea (tekmat) }\end{array}$ & Fiche & $\begin{array}{l}\text { (Elizabeth et al., } \\
2014)\end{array}$ \\
\hline & & Zikita (Amh.) & $\mathrm{S}$ & $\begin{array}{l}\text { Diarrhea } \quad \& \\
\text { Bilharziasis }\end{array}$ & & (Getnet et al., 2015) \\
\hline & & Zigita (Amh.) & $\mathrm{R}$ & Bloody diarrhea & Libo Kemkem & (Getnet et al., 2015) \\
\hline & & ------ & $\mathrm{R} \& \mathrm{~B}$ & $\begin{array}{l}\text { Vomiting and St- } \\
\text { omach problem }\end{array}$ & Gindeberet & $\begin{array}{l}\text { (Gidey and Samuel, } \\
\text { 2005) }\end{array}$ \\
\hline & & Digita (Amh.) & $\mathrm{L}$ & Diarrhea & West Gojjam & (Getaneh et al., 2014) \\
\hline \multirow{5}{*}{ 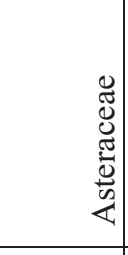 } & \multirow{5}{*}{$\Delta \stackrel{\mathrm{E}}{\mathrm{E}}$} & ------- & $\mathrm{L}$ & Anti-dysentry & Bale zone & (Nasir et al., 2011) \\
\hline & & Girawa (Amh.) & $\mathrm{L}$ & Abdominal pain & Fiche & (Abiyu et al., 2014) \\
\hline & & Ebicha (Oro.) & $\mathrm{L}$ & Diarrhea & A/Negelle & (Gemedo et al., 2014) \\
\hline & & Ebicha (Oro.) & $\mathrm{L}$ & Diarrhea & Guji & $\begin{array}{l}\text { (Genene and Reddy, } \\
\text { 2015) }\end{array}$ \\
\hline & & Ebicha (---) & $\mathrm{L}$ & Diarrhea & SNNPR & (Fisseha et al., 2009) \\
\hline \multirow{7}{*}{ 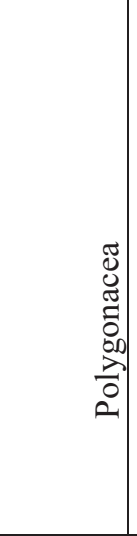 } & \multirow{7}{*}{ 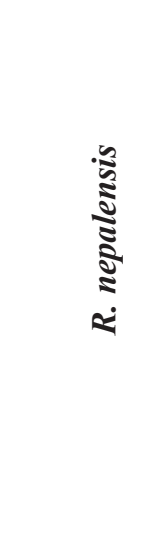 } & Shabbee (Oro.) & $\mathrm{R}$ & Diarrhea & Mana Angetu & (Ermias et al., 2008) \\
\hline & & Shabbee (Oro.) & $\mathrm{R}$ & Stomach problems & $\begin{array}{l}\text { Odo Bulu- } \\
\text { Demaro, Bale }\end{array}$ & (Rainer et al., 2011) \\
\hline & & Tult (Oro.) & $\mathrm{R}$ & $\begin{array}{l}\text { Stomach } \\
\text { problems }\end{array}$ & Gimbii & (Balcha Abera , 2014) \\
\hline & & Lut (Amh.) & $\mathrm{R}$ & $\begin{array}{l}\text { Stabbing pain, } \\
\text { Diarrhea }\end{array}$ & Fiche & (Abiyu et al., 2014) \\
\hline & & Tult (Amh.) & $\mathrm{R}$ & \begin{tabular}{|l} 
Tonsillitis and \\
diarrhea
\end{tabular} & Libo Kemkem & (Getnet et al., 2015) \\
\hline & & $\begin{array}{l}\text { Muca-araba } \\
\text { (Oro.) }\end{array}$ & $\mathrm{R}$ & Abdominal colic & Jimma & (Mesfin et al., 2003) \\
\hline & & Tult (Amh.) & $\mathrm{R}$ & \begin{tabular}{|l}
$\begin{array}{l}\text { stomach } \\
\text { (megagna) }\end{array}$ \\
\end{tabular} & Fiche & $\begin{array}{l}\text { (Elizabeth et al., } \\
\text { 2014) }\end{array}$ \\
\hline
\end{tabular}

Key: Plant parts: Bark (B), Flower (F), Leaf (L), Root (R) and Seed (S); Study area: Southern Nations, Nationalities and Peoples Regional State (SNNPR) Plant local names: Oromic language (Oro.), Amharic language (Amh.)

\subsection{The Test Organisms}

\subsubsection{Escherichia coli}

The genus of the bacterium E. coli is named for a scientist, German Pediatrician Theodor Escherich, whereas its specific epithet, coli, reminds us that $E$. coli live in the colon, or large intestine. He isolated the bacterium in 1885 from feces of infants with diarrhea. Later on, it was observed that the organism is a commensal of gastrointestinal tract and pathogenic and commensal strains can be distinguished by serotyping. Enterohaemorrhagic strains of $E$. coli have emerged as important enteric pathogens in recent years (Gerard et al., 2010). E. coli is a gram-negative bacterial pathogen that causes many infectious diseases in human such as urinary tract infections and common intestinal diseases. Especially Enteropathogenic Escherichia coli (EPEC) that adheres to intestinal epithelial cells, causing diarrhea and constitutes a significant risk to human health that remains an important cause of infant mortality in developing countries (Matias et al. 2011).

Due to the ease of access of pathogens ingested with food, the human gastro-intestinal tract is susceptible to diarrhoeagenic E. coli infections. Several E. coli pathogens have been implicated with diarrhoeal illness, a major public health problem worldwide, with over 2 million deaths occurring each year (www.who.int); The major categories of diarrhoeagenic $E$. coli strains include enteropathogenic E. coli (EPEC), enterotoxigenic E. coli (ETEC), enteroinvasive E. coli (EIEC), enterohemorrhagic E. coli (EHEC) enteroaggregative E. coli (EAEC), and diffuse adhering E. coli (DAEC) (Huiwen et al., 2005). As briefly described in table 3 each of these diarrhoeagenic $E$. coli strains characterized by their own diarrheal disease and how human beings get infected by 
disease they develop.

Table 3: Diarrhoeagenic groups of Escherichia

\begin{tabular}{|c|c|c|}
\hline Group Designation & Disease, Site of Infection & Pathogenic Mechanism \\
\hline Enteropathogenic (EPEC) & Watery diarrhea, small intestine & Adherence \\
\hline Enteroinvasive (EIEC) & $\begin{array}{l}\text { Watery diarrhea followed by bloody } \\
\text { diarrhea, colon }\end{array}$ & Invasion \\
\hline Enterotoxigenic (ETEC) & Watery diarrhea, small intestine & $\begin{array}{l}\text { Heat-stable and/or heat- } \\
\text { labile toxin }\end{array}$ \\
\hline $\begin{array}{l}\text { Shiga-toxin producing (STEC) Also } \\
\text { known as: } \\
\text { Enterohemorrhagic } \\
\text { Verotoxigenic (VTEC) }\end{array}$ & $\begin{array}{l}\text { Watery diarrhea, sometimes bloody, } \\
\text { especially for } \mathrm{O} 157: \mathrm{H} 7 \text {, colon }\end{array}$ & $\begin{array}{l}\text { Shiga toxins, type } 1 \\
\text { and/or type } 2\end{array}$ \\
\hline Enteroaggregative (EaggEC) & hea, small intestine and colon & Adherence \\
\hline Diffuse adhering (DAEC) & Watery diarrhea, small intestine & Adherence \\
\hline
\end{tabular}

Source: Emanuel and Lorrence (2009)

\subsubsection{Staphylococcus aureus}

Staphylococcus aureus (a gram-positive coccus) was discovered in 1880 by the surgeon Sir Alexander Ogston. He observed grape-like clusters of bacteria when examining a purulent discharge from patients with postoperative wounds during microscopy. He named them staphylé, the Greek expression for a bunch of grapes. In 1884, Rosenbach succeeded in isolating yellow bacterial colonies from abscesses and named them S. aureus, "aureus" from the Latin word for golden. Colonization with $S$. aureus is an important risk factor for subsequent S. aureus infection (Wertheim et al., 2004; Lowy, 1998).

Staphylococcus aureus belongs to the family Micrococcaceae and is part of the genus Staphylococcus, which contains more than 30 species such as S. epidermidis, S. saprophyticus and S. haemolyticus. Among the staphylococcal species, $S$. aureus is by far the most virulent and pathogenic for humans. Staphylococcus aureus is a $1 \mu \mathrm{m}$, Gram-positive cell that in the laboratory may be observed as single cells, in pairs or as grape-like irregular clusters. It is characterized as coagulase negative and catalase positive, non-motile, non-spore-forming and as facultative anaerobic (Washington, 2006).

Staphylococcus aureus is generally thought of as an extracellular pathogen, but it can be internalized by a variety of cell types in vitro (eg, fibroblasts, osteoblasts, keratinocytes, and endothelial cells (Hauck C, 2006). Staphylococcus aureus causes a wide range of infections from a variety of skin, wound and deep tissue infections to more life-threatening conditions such as pneumonia, endocarditis, septic arthritis and septicemia. In addition, $S$. aureus may also cause food poisoning, scalded-skin syndrome and toxic shock syndrome, through production of different toxins (Washington, 2006).

Staphylococcus aureus usually grows on the nasal membranes and skin; it also is found in the gastrointestinal and urinary tracts of warm-blooded animals which is a major cause of food poisoning caused by ingestion of improperly stored or cooked food in which S. aureus has grown (Prescott et al., 2008).

Staphylococcus aureus is very resistant to heat, drying, and radiation; it is found in the nasal passages and it is also a frequent cause of skin lesions on the hands. From these sources it can readily enter food. If the bacteria are allowed to incubate in certain foods, they produce heat-stable enterotoxins that render the food dangerous even though it appears normal. Once the bacteria have produced the toxin, the food can be extensively and properly cooked, killing the bacteria without destroying the toxin. Intoxication can therefore result from food that has been thoroughly cooked. Thirteen different enterotoxins have been identified; enterotoxins A, B, C1, C2, $\mathrm{D}$, and $\mathrm{E}$ are the most common. These toxins appear to act as neurotoxins that stimulate vomiting through the vagus nerve (Prescott et al., 2008; Gerard et al., 2010).

Typical symptoms include severe abdominal pain, cramps, diarrhea, vomiting, and nausea. The onset of symptoms is rapid (usually 1 to 8 hours) and of short duration (usually less than 24 hours). Prevention and control involve avoidance of food contamination, and control of personnel responsible for food preparation and distribution (Prescott et al., 2008). Nearly any food can be contaminated with S. aureus, but those with a starch or cream base are most likely candidates. Cream pies, dairy products, poultry products, and picnic foods such as potato salad are common culprits. Contamination is difficult to detect because it produces no change in the food's appearance, taste, or odor (Jacquelyn, 2008).

\subsubsection{Salmonella typhi}

Salmonella is the causative agent of salmonellosis. It is a rod-shaped gram-negative facultative anaerobe bacterium belonging to the Enterobacteriaceae family. Among more than 2,300 closely-related Salmonella serovars recognized, S. typhi and Paratyphi are pathogenic exclusively for humans, and cause systemic infections and typhoid fever (McClelland et al., 2001). Salmonellosis is more prevalent in developing parts of the world in Africa, Asia, and South America.Typhoid fever is an acute, life-threatening febrile illness caused by the bacterium S. typhi and Paratyphi, and there are estimated 20 million cases and 200,000 deaths worldwide each 
year (Crump et al., 2004).

Salmonella organisms penetrate the mucosa of both small and large bowel, coming to lie intracellularly where they proliferate. After ingestion in food or water, typhoid organisms pass through the pylorus and reach the small intestine. They rapidly penetrate the mucosal epithelium via either microfold cells or enterocytes and arrive in the lamina propria, where they rapidly elicit an influx of macrophages (Mp) that ingest the bacilli but do not generally kill them. Acute typhoid fever is characterized by prolonged fever, disturbances of bowel function (constipation in adults, diarrhoea in children), headache, malaise and anorexia (WHO, 2003).

\subsubsection{Pseudomonas aerugenosa}

Pseudomonas aeruginosa is a motile, non-fermenting bacterium, Gram-negative organism belonging to the family Pseudomonadaceae, opportunistic pathogen capable of infecting humans with compromised natural defenses and causing severe pulmonary disease. It is one of the leading pathogen associated with nosocomial (hospital-acquired, infections are those not present or incubating at the time of hospital admission, but usually develop post-admission infections) (Alaa Alhazmi, 2015). Pseudomonas aeruginosa is an opportunistic pathogen familiar to every hospitalist and intensivist. It is a frequent cause of nosocomial infections, many of which are responsible for substantial mortality even when treated with appropriate antibiotics (Juhas et al., 2005).

\subsubsection{Shigella dysentery}

Shigella organisms are a group of gram negative, facultative intracellular pathogens. They were recognized as the etiologic agents of bacillary dysentery or shigellosis in the 1890s. Shigella were discovered over 100 years ago by a Japanese microbiologist named Shiga, for whom the genus is named. Shigella was adopted as a genus in the 1950s. These organisms are members of the family Enterobacteriaceae and tribe Escherichieae; they are grouped into 4 species: Shigella dysenteriae, Shigella flexneri, Shigella boydii, and Shigella sonnei, also known as groups A, B, C, and D, respectively (Gomez et al., 1997).

\subsection{Extraction Solvents}

Several investigators on medicinal plants have indicated that organic solvents such as alcohols are extensively used for crude extraction before being re extracted to obtained purified active compounds using some other organic solvents (Francis, and Richard, 2007; Anibijuwon et al., 2012). Polar and ionic solutes are easily dissolved in the polar solvents. When both of the solutes and the solvents are polar, they have attraction between each other (Francis, and Richard, 2007). Solvents are generally classified by their polarity, and considered either polar or non polar, as indicated by the dielectric constant (Table 4). The greater the dielectric constant, the greater the polarity. Solvents with dielectric constants greater than about 5 are considered "polar" and those with dielectric constants less than 5 are considered "nonpolar" (http://chemwiki.ucdavis). Plant extracts are expected to be polar compounds which indicate that they dissolve in polar solvents and results clearly showed that utilization of polar solvent enable extraction of significant amounts of plant extracts (Farooq and Roman, 2012). Polar protic solvents, especially water (78.5) and methanol (32.6) have larger value of polarity, hence they can dissolve plant materials better than the other solvents (Francis, and Richard, 2007).

Generally higher extract yields, phenolic contents and plant material antioxidant activity were obtained using aqueous organic solvents, as compared to the respective absolute organic solvents (absolute methanol and aqueous methanol, i.e., methanol: water, 80:20) (Bushra et al., 2009). Methanol shows both polar and non-polar characteristics. Consequently, these characteristics give methanol the unique ability to be used in an extensive range of applications (Esteban et al., 2006). 
Table 4: Common solvents used in organic chemistry

\begin{tabular}{|c|c|c|}
\hline Solvent & Boiling Point, Celsius & $\begin{array}{l}\text { Dielectric } \\
\text { Constant }\end{array}$ \\
\hline \multicolumn{3}{|c|}{ Non-Polar Solvents } \\
\hline Pentane, $\mathrm{C}_{5} \mathrm{H}_{12}$ & 36 & 1.8 \\
\hline Hexane, $\mathrm{C}_{6} \mathrm{H}_{14}$ & 69 & 1.9 \\
\hline Benzene, $\mathrm{C}_{6} \mathrm{H}_{6}$ & 80 & 2.3 \\
\hline Chloroform, $\mathrm{CHC}_{13}$ & 61 & 4.8 \\
\hline Diethyl ether, $\left(\mathrm{CH}_{3} \mathrm{CH}_{2}\right)_{2} \mathrm{O}$ & 35 & 4.3 \\
\hline 1,40-Dioxane,Cyc- $\left(\mathrm{CH}_{2} \mathrm{CH}_{2} \mathrm{OCH}_{2} \mathrm{CH}_{2} \mathrm{O}\right)$ & 101 & 2.3 \\
\hline \multicolumn{3}{|c|}{ Polar Parotic Solvents } \\
\hline Water, $\mathrm{H}_{2} \mathrm{O}$ & 100 & 78.5 \\
\hline Methanol, $\mathrm{CH}_{3} \mathrm{OH}$ & 65 & 32.6 \\
\hline Ethanol, $\mathrm{CH}_{3} \mathrm{CH}_{2} \mathrm{OH}$ & 78.5 & 24.3 \\
\hline isopropyl alcohol, $\mathrm{CH}_{3} \mathrm{CH}(\mathrm{OH}) \mathrm{CH}_{3}$ & 82 & 18 \\
\hline acetic acid, $\mathrm{CH}_{3} \mathrm{COOH}$ & 118 & 6 \\
\hline \multicolumn{3}{|c|}{ Polar Aprotic Solvents } \\
\hline Dichloromethane, $\mathrm{CH}_{2} \mathrm{Cl}_{2}$ & 40 & 9.1 \\
\hline tetrahydrofuran (THF), cyc - $\left(\mathrm{CH}_{2}\right)_{4} \mathrm{O}$ & 66 & 7.5 \\
\hline ethyl acetate, $\mathrm{CH}_{3} \mathrm{C}(\mathrm{O}) \mathrm{OCH}_{2} \mathrm{CH}_{3}$ & 77 & 6 \\
\hline Acetonitrile, $\mathrm{CH}_{3} \mathrm{CN}$ & 81.6 & 37.5 \\
\hline dimethylformamide (DMF), $\mathrm{HCON}\left(\mathrm{CH}_{3}\right)_{2}$ & 153 & 38 \\
\hline dimethyl sulfoxide (DMSO), $\mathrm{CH}_{3} \mathrm{SOCH}_{3}$ & 189 & 47 \\
\hline Acetone, $\mathrm{CH}_{3} \mathrm{COCH}_{3}$ & 56.5 & 21 \\
\hline hexamethylphosphoric triamde (HMPT), $\left[\left(\mathrm{CH}_{3}\right)_{2} \mathrm{~N}\right]_{3} \mathrm{PO}$ & 232 & 30 \\
\hline
\end{tabular}

Source: (Francis and Richard, 2007).

\section{CONCLUSIONS}

This review stated that plants are valuable sources for new compounds and should receive special attention in research strategies to develop new antimicrobials urgently required in the near future. The importance of medicinal plants and traditional health systems in solving the health care problems of the world is gaining increasing attention. Because of this resurgence of interest, the research on plants of medicinal importance is growing phenomenally at the international level, often to the detriment of natural habitats and protects populations in the countries of origin. In Ethiopia since many years the peoples are using plants as the medicine. The plant contains various phytochemical, which would act on the pathogenic microorganism and hinder their growth. The scanty of researches are available on antibacterial activity of medicinal plants in Ethiopia, but still we need to explore many antimicrobial compounds from plants. These kinds of the research are baseline information for the development of new drugs, which is bench mark in science. Commercially many synthetic drugs are available in market, but microorganisms are resistant to many antibiotics. So research should need to develop new synthetic compound from the plant source.

\section{Competing Interests}

The authors declare that they have no competing interests.

\section{Acknowledgments}

The authors are thankful to library and ICT office of Madda Walabu University for providing the facilities to prepare this review paper.

\section{REFERENCE}

Abdelraouf A. Elmanama, . (2009). General Microbiology Laboratory Manual. Gaza: Medical Technology Department Islamic University.

Abiyu Enyew, Zemede Asfaw, Ensermu Kelbessa and Nagappan, R., (2014). "Ethnobotanical Study of Traditional Medicinal Plants in and Around Fiche District, Central Ethiopia." Research J Bio Sc. 6(4):154167.

Abubakar, MG., Ukwuani, AN. and Sheshu, RA. (2008). "Phytochemical screening and antibacterial activity of Tamarindus indica pulp Extract." Asian J Biochem 3(2):134-138.

Adenisa, SK., Idowu, O. and Ogundaini, AO.1. (2000). "Antimicrobial constituents of the leaves of Acalypha wilkesiana and Acalypha hispida." Phytotherapy Research 14:371-374. 
Agbogidi, O.M. and Akpomorine, M.O.(2013). "Health and nutritional benefits of bitter leaf." Int.J.A.PS.BMS 2(3):164-170.

Ahmad, I. and Beg, AZ. (2001). "Antimicrobial and phytochemical studies on 45 Indian medicinal plants against multiple drug resistant human pathogens." J. Ethanopharma 74:113-123.

Alaa Alhazmi, (2015). "Pseudomonas aeruginosa - Pathogenesis and Pathogenic Mechanisms." International Journal of Biology Vol. 7: No. 2.

Anibijuwon, B.O. Oladejo, D.O. Adetitun and .M. Kolawole (2012). "Antimicrobial Activities of Vernonia amygdalina Against Oral Microbes." Global Journal of Pharmacology 6 (3): 178-185.

Balcha Abera, (2014). "Medicinal plants used in traditional medicine by Oromo people, Ghimbi District, Southwest Ethiopia." Abera J. of Eth. bio. and Eth. med. 10:40.

Balunas, M. J. and Kinghorn, A. D., (2005). "Drug discovery from medicinal plants." Life Sciences 78: pp 431 441.

Bushra Sultana, Farooq Anwar and Muhammad Ashraf (2009). "Effect of Extraction Solvent/Technique on the Antioxidant Activity of Selected Medicinal Plant Extracts." Molecules 14: 2167-2180.

Cain, D., Hershell Hanks, Mary Weis, Carroll Bottoms, and Jonathan Lawson, (2013). Microbilogy Laboratory Manual. Collin County Community College District, McKinney, TX.

Crump JA, Luby SP, Mintz ED (2004). "The global burden of typhoid fever." Bull World Health Organ 82:346353.

Dubey, R., Dubey, K., Sridhar, C., and Jayaveera, KN. (2011). "Human Vaginal Pathogen inhibition studies on aqueous, methanolic and saponins extracts of stem Barks of Ziziphus mauritiana." Int. J.Pharm. Sci. Res 2(3): 659-663.

Elizabeth A., Wohlmuth, H., Zemede Asfaw and Tesfaye Awas (2014). "The current status of knowledge of herbal medicine and medicinal plants in Fiche, Ethiopia." J. of Ethinobiology 1-32.

Emanuel Goldman and Lorrence H. Green, (2009). Practical hand book of Microbiology. second edition.

Ermias Lulekal, Ensermu Kelbessa, Tamrat Bekele and Haile Yineger (2008). "An ethnobotanical study of medicinal plants in Mana Angetu." J. of Ethnobio. and Ethnomed. 10:4-10.

Esteban, A., Hernandez, V. and Lunsford, K. (2006). "Exploit the Benefits of Methanol." Bryan R. and Engi. 121.

Farooq, A. and Roman, P.(2012). "Effect of solvents extraction on total phenolics and antioxidant activity of extracts from flaxseed (linum usitatissimum 1.)." Acta Sci. Pol., Technol. Aliment 11(3): 293-301.

Fisseha Mesfin, Sebsebe Demissew and Tilahun Teklehaymanot (2009). "An ethnobotanical study of medicinal plants in Wonago Woreda, SNNPR, Ethiopia." J. of Ethnobio. and Ethnomed. 10:5-28.

Francis, A. Carey and Richard J.V. (2007). Advanced Organic Chemistry. FIFTH Edition. New York,: Springer Science+Business Media.

Gemedo Misha, Yarlagadda, R. and Messay Wolde-Mariam (2014). "Knowledge, Attitude, Practice and Management of Traditional Medicine among People of Shopa Bultum, Southeast Ethiopia." Res. J. of Pharma., Bio. and Chem. Sc. 152-170.

Genene Bekele and Reddy, R. (2015). "Ethnobotanical Study of Medicinal Plants Used to Treat Human Ailments by Guji Oromo Tribes in Abaya District, Borana, Oromia, Ethiopia." Universal J. of Plant Sc. 3(1): $1-8$.

Gerard J. Tortora, Berdell R. Funke, Christine L. Case, (2010). Microbiology. 10th.

Gerard J. Tortora, Berdell R. Funke, Christine L. Case.(2010). Microbiology: an introduction. 10th ed. United States of America.

Getaneh Gebeyehu, Zemede Asfaw, Abiyu Enyew and Nagappan, R. (2014). "Ethnobotanical study of traditional medicinal plants and their conservation status in Mecha Wereda, West Gojjam zone of Ethiopia." Int. J. of Pharma. and Health care Res. 2 (3):137-154.

Getnet Chekole, Zemede Asfaw and Ensermu Kelbessa (2015). "Ethnobotanical study of medicinal plants in the environs of Tara-gedam and Amba remnant forests of Libo Kemkem District, northwest Ethiopia." J.L of Ethnobio. 1-38.

Gidey Yirga and Samuel Zeraburk, (2005). "Ethnobotanical study of traditional medicinal plants in Gindeberet district, western Ethiopia." Afr. Society for Sc. Res. 61-67.

Gislene, G. F., Freitas, C. and Giuliana, L.S. (2000). "Antibacterial activity of plant extracts and phytochemicals on antibiotic resistant." Brazilian J. of Microbio. 247-256.

Gomez HF, Cleary TG (1997). Shigella species Principles and Practice of Pediatric Infectious Diseases. New York, NY: Churchill Livingstone.

Haile Yineger, Ensermu Kelbessa, Tamrat Bekele and Ermias Lulekal (2008). "Plants used in traditional management of human ailments at Bale Mountains National Park, Southeastern Ethiopia." J. of Med. Plants Res. 2(6):132-153.

Hauck, (2006). "Sticky connections: extracellular matrix protein recognition and integrin-mediated cellular 
invasion." Curr Opin Microbiol 9:5-11.

Hosten, K., Marston, A. and Ndjoko, K. (2000). "Potential for African plants as a source of drugs." Current Organic Chem. 4: 973-1010.

Huiwen Deborah Chen, Gad Frankel (2005). "Enteropathogenic Escherichia coli: unravelling pathogenesis." FEMS Microbiology Reviews 29 (2005) 83-98.

Hussain, H., Badawy, A., Elshazly, A., Elsayed, A., Krohn, K., Riaz, M., Schulz, B. (2011). "Chemical Constituents and Antimicrobial Activity of Salix subserrata." Rec. Nat. Prod. 5(2):133-137.

Ieven, M., Vanden Bergh, D.A., Valientincok, A.J. and Lammens, E. (1979). "Screening of higherplants for biological activities." Planta Medica 36: 311-321.

Jacquelyn, G. Black, (2008). Microbiology. 7th. edition

Juhas M, Eberl L, Tummler B. Quorum sensing (2005). "the power of cooperation in the world of Pseudomonas." Environ Microbiol 7(4):459-471.

Lalitha, P., Arathi, KA., Shubashini, K., Sripath, I., Hemalatha, S., Jayanthi, P. (2010). "Antimicrobial Activity and Phytochemical Screening of an Ornamental Foliage Plant, Pothos aurea (Linden ex Andre)." An Int. J. of Chem. 1 (2): 63-71.

Lategan, CA., Campbell, WE., Seaman, T., Smith, PJ. (2009). "The bioactivity of novel furanoterpenoids isolated from Siphonochilus aethipicus." J.l of Ethnopharma. 121: 92-97.

Lowy, F.D., (1998). "Staphylococcus aureus infections." N Engl J Med 339: 520-532.

Mahesh, B. and Satish, S.(2008). "Antimicrobial Activity of Some Important Medicinal." World Journal of Agricultural Sciences 839-843.

Matias EF, Santos KK, Almeida TS, Costa JG, Coutinho HD (2011). "Phytochemical prospection and modulation of aminoglycoside antibiotic activity by Croton campestris." A. Chemotherapy 57(4):305-9.

McClelland M, Sanderson KE, Spieth J,(2001). "Complete genome sequence of Salmonella enterica serovar Typhimurium." LT2.Nature 413:852-856.

Meseret Egigu and Mekonnen Abebe, (2014). "Ethnomedicinal use of plants from Gololcha District, Bale Zone of Oromiya region, Ethiopia." J. of Ethnobio. and Tradi. Med. Photon 121: 773-786.

Mesfin Tadesse, Debela Hunde and Yehenew Getachew (2003). "Survey of Medicinal Plants Used to Treat Human Diseases in Seka Chekorsa Jimma zone, Ethiopia." Original Article 89-107.

Mthabe, MC., Niikolova, RV., Lal, IN., Nyazema, NZ. (2006). "Antibacterial activities of medicinal plants used for the treatment of diarrhoea in Limpopo Province." S. Afri. J. Ethnopharma. 105:286-293.

Nakamura, C. V., Ueda-Nakamura, T., Bando, E., Melo, A. F., Cortez, D. A., Dias Filho, B. P.(1999). "Antibacterial Activity of Ocimum gratissimum L. Essential Oil." Mem. Inst. Oswaldo Cruz 94: 675-678.

Nasir Tajure, Mohammed Adem and Jaya, N. (2011). "Ethnobotanical survey of medicinal plants in the Southeast Ethiopia used in traditional medicine." Spatula DD 1(3): 153-158.

Njoroge, GN. and Busman, RW.(2007). "Ethnotherapeutic management of skin diseases among the Kikuyu of Central Kenya." J. Ethnopharm 111:303-307.

Ouattara, K., Koné, T., Yeo, D., Coulibaly, A. (2013). "Antifungal activity of the aqueous and ethanolic extracts of Thonningia sanguinea,Vahl (Balanophoraceae)." J.l of Drug Del. and Therap. 3(1): 29-32.

Parekh, J. and Chanda, S.V. (2007). "In vitro Antimicrobial Activity and Phytochemical Analysis of Some Indian Medicinal Plants." Turk J Biol. 31:53-58.

Pavithra, PS., Janan, VS., Charumath, KH., Indumathy, R., Potala, S. and Verma, R.S. (2010). "Antibacterial activity of the plant used in Indian herbal medicine." Int. J. of green pharma. 10: 22-28.

Preethi, R., Devanathan, VV. and Loganathan, M. (2010). "Antimicrobial and Antioxidant Efficacy of Some Medicinal Plants Against Food Borne Pathogens." Adv. in Bio.Res. (Adv. in Bio.Res) 4 (2): 122-125.

Prescott, Harley and Klein's, (2008). Microbiology. Seventh Edition. New York: Colin Wheatley/Janice RoerigBlong.

Rainer, W B., Swartzinsky, P., Aserat Worede and Evangelista, P. (2011). "Plant use in Odo Bulu and Demaro, Bale region, Ethiopia." J Ethnobio. Ethnomed. 7:28.

Satyajit D, Zahid L, Alexander I (2001). "Natural product isolation Method." Biotechnol J 20:1-7.

Shahidi Bonjar, G. H. (2004). "Evaluation of Antibacterial properties of Iranian Medicinal plants against Micrococcus aureus, Serratia marcescens, Klebsiella pneunomiae and Bordella bronchoseptica (2004)." Asian J. of Sc. 3(1):82-86.

Sharma, A. (2011). "Antibacterial activity of ethanolic extracts of some arid zone plants." Int. J. of Pharm.Tech. Res. 3(1):283-286.

Srivastava, J., Lambert, J. and Vietmeyer, N. (1996). "Medicinal plants: An expanding role in development." World Bank Technical Paper, No. 320.

Tona, L., Kambu, N., Ngimbi, K., Cimanga and Vlietinck, A.J. (1998). "Antiamoebic and phytochemical screening of some Congolese medicinal plants." J. Ethnopharma. 61: 57-65.

Wanyoike, G., Chhabra, R. and Omar, S. (2004). "Brine shrimp toxicity and antiplasmodial activity of five 
Kenyan medicinal plants." J. of Ethnopharma. 90(1):129-133.

Washington, A.S., Janda William, Koneman Elmer, Procop Gary, Schreckenberger Paul ,Woods Gail, ( 2006). Koneman's Color Atlas and Textbook of Diagnostic Microbiology Lippincott Williams \& Wilkins. Philadelphia.

Wertheim, H.F., Vos, M.C., Ott, A., van Belkum, A., Voss, A., Kluytmans, J.A., van Keulen, P.H.,Vandenbroucke-Grauls, C.M., Meester, M.H., Verbrugh, H.A.,( 2004). "Risk and outcome of nosocomial Staphylococcus aureus bacteraemia in nasal carriers versus non-carriers." Lancet 364: 703-705.

World Health Organization (2003). Basic laboratory procedures in clinical bacteriology. Second edition. Geneva.

World Health Organization (2003). Communicable Disease Surveillance and Response Vaccines and Biologicals. Geneva, Switzerland. 